\title{
Polyglandular autoimmune syndrome type III: Two cases
}

\author{
Umang G Thakkar ${ }^{1}$, Aruna V Vanikar $^{2}$, Hargovind L Trivedi ${ }^{3}$ \\ Sri Lanka Journal of Child Health, 2013; 42: 217-218
}

(Keywords: Hypothyroidism; diabetes mellitus type 1; pernicious anemia)

\section{Introduction}

Polyglandular type 111 autoimmune syndrome (PGAS type III) is a rare condition with unknown prevalence typically observed in middle-aged women but can occur in persons of any age without any racial or ethnic difference ${ }^{1}$. Type III involves one of the following: (a) Thyroid autoimmune disease and type 1 diabetes mellitus /Insulin dependent diabetes mellitus (IDDM), (b) Thyroid autoimmune disease and pernicious anaemia, (c) Thyroid autoimmune disease as well as one or more of vitiligo, alopecia and organ-specific autoimmune disease not in categories (a) and (b) are found ${ }^{2}$.

\section{Case 1}

A seventeen year old female patient with a weight of $56 \mathrm{~kg}$, a height of $168 \mathrm{~cm}$ and a body surface area (BSA) of $1.61 \mathrm{~m}^{2}$ came to the outpatient department (OPD). She is a known case of IDDM since 10 years of age without a significant family history of diabetes mellitus and daily took insulin of $50 \pm 5$ IU per 24 hours. She was vaccinated according to age. She was diagnosed as having hypothyroidism during hospitalization in January, 2008 at which time she had a serum T3 of $1.1 \mathrm{ng} /$ $\mathrm{ml}$, (normal range: $0.52-1.85 \mathrm{ng} / \mathrm{ml}$ ), a serum $\mathrm{T} 4$ of $0.84 \mu \mathrm{g} / \mathrm{dl}$ (normal range: 4.8-11.6 $\mu \mathrm{g} / \mathrm{dl}$ ) and a serum. TSH $>40 \mu \mathrm{U} / \mathrm{ml}$ (normal range: 0.28 to 6.82 $\mu \mathrm{U} / \mathrm{ml}$ ). She was started on oral thyroxine $50 \mu \mathrm{g} /$ day. She had positive anti thyroid antibodies by haemagglutination assay the anti-microsomal antibody titre being 1:6400 IU/ml $\quad(>1: 100$ positive). During further evaluation, glutamic acid

\footnotetext{
${ }^{1}$ Assistant Professor. Department of Stem Cell Therapy \& Regenerative Medicine \& Paediatrics, ${ }^{2}$ Professor and Head. Department of Pathology, Laboratory Medicine, Transfusion Services \& Immunohematology, ${ }^{3}$ Professor, Department of Nephrology \& Stem Cell Therapy \& Regenerative Medicine, G. R. Doshi \& K. M. Mehta Institute of Kidney Diseases \& Research Centre Dr. H.L. Trivedi Institute of Transplantation Sciences, Civil Hospital Campus, Ahmedabad, Gujarat, India
}

(Received on 7 December 2012: Accepted after revision on 18 January 2013) decarboxylase (GAD) antibody titre was >2000 IU/ $\mathrm{ml}$ (normal range $<10 \mathrm{IU} / \mathrm{ml}$ ), anti-islet cell (ISL) antibody titre by immune fluorescent assay was $<1: 5$ (negative) and insulin antibody was $<12 \mathrm{U} /$ $\mathrm{ml}$ (negative). She had fasting and post prandial blood sugars of $458 \mathrm{mg} / \mathrm{dl}$ and $>500 \mathrm{mg} / \mathrm{dl}$, respectively. Her serum C-peptide was $0.01 \mathrm{ng} / \mathrm{ml}$, HbA1c was $8.1 \%$, urine sugar was +4 and serum acetone was absent. Plasma adrenocorticotropic hormone (ACTH) was $33.2 \mathrm{pg} / \mathrm{ml}$ and plasma cortisol was $5.2 \mathrm{mcg} / \mathrm{dl}$ (normal). Renal function tests (RFTs), liver function tests (LFTs), lipid profile, serum electrolytes and coagulation profile were normal. Radiological evaluation and cardiac evaluation were within normal limits. No diabetic retinopathy was observed on fundus examination. On follow-up, insulin requirement of this patient was $50 \mathrm{IU} / 24$ hours, maintaining $151 \mathrm{mg} \%, 217$ $\mathrm{mg} \%$ of fasting blood sugar (FBS) and post prandial blood sugar (PPBS) respectively with HbA1c $6.9 \%$, with oral thyroxine $50 \mu \mathrm{g}$ daily and maintaining the euthyroid status.

\section{Case 2}

A nineteen year old male patient with a weight of $62 \mathrm{~kg}$, a height of $165 \mathrm{~cm}$ and a BSA of $1.06 \mathrm{~m}^{2}$ came to the OPD. He is a known case of IDDM since 17 years of age without a significant family history of diabetes mellitus and daily took insulin of $70 \pm 5$ IU per 24 hours. He was vaccinated according to age. He was diagnosed as having hypothyroidism during hospitalization in January, 2010 at which time he had a serum T3 of $0.6 \mathrm{ng} / \mathrm{ml}$ (normal range: $0.52-1.85 \mathrm{ng} / \mathrm{ml}$ ), a serum T4 of 0.9 $\mu \mathrm{g} / \mathrm{dl}$ (normal range: $4.8-11.6 \mu \mathrm{g} / \mathrm{dl}$ ) and a serum. $\mathrm{TSH}>100 \mu \mathrm{U} / \mathrm{ml}$ (normal range: 0.28 to $6.82 \mu \mathrm{U}$ $/ \mathrm{ml})$. He was started on oral thyroxine $100 \mu \mathrm{g} /$ day. He had positive anti thyroid antibodies by enzyme-linked immunosorbent assay (ELISA), including an anti-microsomal antibody titre of $816.8 \mathrm{IU} / \mathrm{ml}(>40$ positive $)$ and an antithyroglobulin antibody titre of $129.3 \mathrm{IU} / \mathrm{ml}(>125$ positive). During further evaluation glutamic acid decarboxylase (GAD) antibody titre was $740 \mathrm{IU} /$ $\mathrm{ml}$ (normal range: $<10 \mathrm{IU} / \mathrm{ml}$ ), anti islet cell (ISL) antibody titre by immune fluorescent assay was negative (1:5) and insulin antibody was $8.87 \mathrm{U} / \mathrm{ml}$ (normal range $<12 \mathrm{U} / \mathrm{ml}$ ). He had fasting and post prandial blood sugars of $251 \mathrm{mg} / \mathrm{dl}$ and $382 \mathrm{mg} / \mathrm{dl}$ 
respectively. His serum C-peptide was $0.1 \mathrm{ng} / \mathrm{ml}$, $\mathrm{HbA} 1 \mathrm{c}$ was $14.2 \%$, urine sugar was +4 and serum acetone was absent. RFTs, LFTs, lipid profile, serum electrolytes and coagulation profile were normal. Radiological evaluation and cardiac evaluation were within normal limits. No diabetic retinopathy was observed on fundus examination. On follow-up, insulin requirement of this patient was $65 \mathrm{IU} / 24$ hours and maintaining $180 \mathrm{mg} \%$ of FBS, $220 \mathrm{mg} \%$ of PPBS with HbA1c $8.6 \%$ and oral thyroxine $100 \mu \mathrm{g}$ daily and maintaining the euthyroid status.

\section{Discussion}

The polyglandular diseases are a series of organspecific autoimmune illnesses characterized by the presence of circulating organ-specific antibodies, even in the absence of overt clinical disease ${ }^{1}$. According to the classification of Neufeld and Blizzard there are four types of polyglandular autoimmune syndrome (PGAS) or autoimmune polyglandular syndromes (APS): types I, II, III and $\mathrm{IV}^{2}$. The hallmark of APS III is the absence of Addison disease ${ }^{3}$. Genetic factors are also involved in the pathogenesis of APS ${ }^{3,4}$. APS 11 and 111 are associated with HLA class II genes, with apparently distinctive HLA alleles for each, often observed in individuals in the same family, suggesting that its inheritance could be due to an autosomal dominant trait with incomplete penetrance $^{3}$. In autoimmune thyroiditis, circulating autoantibodies are capable of reacting in vitro with thyroglobulin, microsomal antigens and other cell surface antigens and may block the action of TSH receptor stimulator by binding to the receptor or by direct inactivation of the stimulating antibody and thus may induce hypothyroidism ${ }^{5}$. In IDDM, cytotoxic autoantibodies to pancreatic $\beta$ cells and anti cytoplasmic islet cell antibodies are also present. In autoimmune thyroiditis and IDDM, lymphocytes produce the migration inhibition factor (MIF) after stimulation with thyroid or pancreatic antigens, and have positive result of MIF tests even in absence of circulating organ specific autoantibodies. ${ }^{5}$. Antibody dependent cell mediated cytotoxicity (ADCC) is a combination of humoral and cellular immunity that require the binding of specific antibodies to their target cells attachment of non-sensitized lymphoreticular cells to $\mathrm{Fc}$ (crystallizable fragment) region of these antibodies which leads to target cell death by an extracellular non phagocytic mechanism ${ }^{6}$. Treatment includes monitoring of glandular functions for early detection of glandular failure, life-long hormone replacement therapy for established glandular failure or failures and familial screening. Goal of pharmacotherapy is to correct hormone deficiencies, prevent complications, and reduce morbidity
It is important to evaluate the patient for another endocrine glandular dysfunction in presence of one glandular dysfunction to rule out autoimmune polyglandular syndrome type III.

\section{Acknowledgments}

We are greatly thankful to our director Dr $\mathrm{H} \mathrm{L}$ Trivedi for giving guidance regarding these cases, and also thankful to our librarian Ms. Jyotsanaben Suthar for her help in literature search and the laboratory staff too for their invaluable help.

\section{References}

1. Basak RC, Chatterjee M, Rassem MW. Autoimmune polyglandular syndrome (type III): Case Report. Kuwait Medical Journal 2007; 39:373-5.

2. Neufeld M, Blizzard RM. Polyglandular autoimmune disease. In: Pinchera A, Doniach D, Fenzi DF, Baschieri L, editors. Autoimmune Aspects of Endocrine Disorders. London, UK: Academic Press; 1980:357-65.

3. Aung K, Salmon M. Autoimmune polyglandular syndrome, type 111 . www.eMedicine.com, 2004; 1-10.

4. Aaltonen $\mathrm{J}$, Björses P. Cloning of the APECED gene provides new insight into human autoimmunity. Annals of Medicine 1999; 31:111-6.

http://dx.doi.org/10.3109/07853899708998786

5. Rose NR, Mackay IR editors. The Autoimmune Diseases. Orlando, Florida: Academic Press, Inc. 1985, pp.161-199

6. Meyerson J, Lechuga-Gomez EE, Bigazzi PE, Walfish PG. Polyglandular autoimmune syndrome: current concepts. Canadian Medical Association Journal 1988; 138:60512. 